\title{
Energy and emission aspects of co-combustion solid recovered fuel with coal in a stoker boiler
}

\author{
Ryszard Wasielewski ${ }^{1,{ }^{*}}$, Krzysztof Głód ${ }^{1}$, and Jolanta Telenga-Kopyczyńska ${ }^{1}$ \\ ${ }^{1}$ Institute for Chemical Processing of Coal, 41-803 Zabrze, Zamkowa 1 St, Poland
}

\begin{abstract}
The results of industrial research on co-combustion of solid recovered fuel (SRF) with hard coal in a stoker boiler type WR-25 has been presented. The share of SRF in the fuel mixture was $10 \%$. During the co-combustion of SRF, no technological disturbances or significant reduction in energy efficiency of the boiler were noted. Obtained $\mathrm{SO}_{2}$, $\mathrm{NO}_{\mathrm{x}}$ and $\mathrm{CO}$ emissions were comparable with coal combustion but dust emissions increased. During combustion of the coal mixture with a $10 \%$ share of SRF in the test boiler WR-25, the emission standards established for the combustion of the dedicated fuel were met. However, comparison of obtained emission results with the emission standards established for co-incineration of waste, revealed the exceedance of permissible levels of $\mathrm{HCl}$, dust, heavy metals, dioxins and furans. Additionally, the residence time of flue gases in over $850^{\circ} \mathrm{C}$ conditions for the test boiler WR-25 was too short ( 1.3 seconds) in refer to the legislative requirements $(2$ seconds) for the thermal conversion of waste.
\end{abstract}

\section{Introduction}

Energy recovery of wastes by using them for production of stable quality parameters fuels and their energy effective and environmentally safe application is a very important issue in the contemporary waste management system. For several years both development of technology of fuel production from wastes and its use has been observed [1-5]. Fuels from waste are widely used in energy-intensive branches of industry, such as production of clinker or paper, but also for production of electrical energy and heat. Numerous research studies are also conducted to broaden the knowledge on phenomena accompanying the process of energy recovery from these fuels [5-6]. Growth of the market for these fuels is also connected with the development of international SRF (solid recovered fuels) classification [1-2].

Searching for new sales markets, the increasing domestic potential of producing fuels from waste looks with hope toward the power engineering [7,8]. One of the barriers is however, current technical level of the boiler installations, including in particular flue gas purification systems [9,10]. Many boiler houses in Poland are equipped with coal boilers with mechanical grate. However, not too much experience has been gained so far in relation to SRF co-combustion in such installations.

\footnotetext{
* Corresponding author: rwasielewski@ichpw.pl
} 
The Institute for Chemical Processing of Coal conducted industrial tests of SRF cocombustion with hard coal in WR-25 stoker fired boiler type installation.

The purpose of the research was assessment of the waste and coal co-combustion impact on performance and operational parameters of the boiler, and also determining the possibility to meet the legislative requirements related to the environment protection by the power engineering installation.

\section{Materials and methods}

The research was of comparative nature and its scope included conducting two parallel series of energy-emission measurements for: combustion of hard coal and combustion of a mix of coal and $10 \%$ of SRF.

Scope of measurements included all emission determinations for co-combustion of waste, as well as verification of process conditions necessary for thermal conversion of waste.

\subsection{Characteristics of the installation}

The WR-25 boiler (of the $23.26 \mathrm{MW}_{\mathrm{t}}$ rated capacity) is a high temperature water-tube boiler with forced draught and blow. Combustion chamber has the following horizontal dimensions: $5.30 \mathrm{~m}$ x $3.90 \mathrm{~m}$. The base fuel for the boiler is fine hard coal. By-products of combustion are: slag and fly ash. The WR-25 boiler is equipped with a two-stage dust removing system from flue gases, consisting of series circuit cyclone dust collectors. Flue gases are discharged to the atmosphere via an emitter of $120 \mathrm{~m}$ height and 5.2 outlet diameter.

\subsection{Research methodology}

Samples of hard coal, SRF and their blends were subject to technical and elemental analysis. Furthermore, bulk density and content of heavy metals were determined. Respective determinations were performed in accordance with the research methodology specified in Polish Standards and research procedures of the Institute for Chemical Processing of Coal.

Samples of slag and fly ash were taken every 60 minutes. After averaging, the samples were tested for combustibles content and for heavy metals content. The research was performed in accordance with the research methodology specified in Polish Standards and research procedures of the Institute for Chemical Processing of Coal.

Determinations of dust concentrations, speed and density of flue gas were performed in accordance with the requirements of the PN-Z-04030-7:1994 standard. Determinations were made by means of the EMIOTEST 2598 gravimetric dust meter, aspiration probe with external filtration, and "S" type impact-pressure tube.

Gas concentration in flue gases was determined by means of GASMET DX 4000 gas analyser with hot measurement path, using the FTIR method, among others concentrations of the following gases were determined: $\mathrm{NO}, \mathrm{NO}_{2}, \mathrm{SO}_{2}, \mathrm{CO}_{2}, \mathrm{CO}, \mathrm{HCl}$ and $\mathrm{HF}$. Composition of flue gas was measured continuously.

Determination of VOCs (Volatile Organic Compounds) was made by means of a portable organic substances analyser of the AWE-PW series.

Sampling procedure and determination of heavy metals concentrations and emissions in flue gases ( $\mathrm{Cd}, \mathrm{Tl}, \mathrm{Sb}, \mathrm{As}, \mathrm{Cr}, \mathrm{Co}, \mathrm{Cu}, \mathrm{Mn}, \mathrm{Ni}, \mathrm{Pb}, \mathrm{V})$ were made in accordance with the PN-EN 14385:2005 standard. 
Samples for determinations of mercury $(\mathrm{Hg})$ concentration and emission were taken in accordance with the PN-EN 13211+AC:2006 standard.

Sampling of polychlorinated dibenzodioxins and polychlorinated dibenzofurans PCDD/DE was made in accordance with the requirements of the PN-EN 1948-1: 2006 standard. The sample was chemically analysed in the accredited laboratory of the Institute of Public Health Ostrava.

To determine how long the flue gases remain in the area of temperature exceeding $850^{\circ} \mathrm{C}$ (in accordance with the requirements specified in the Journal of Laws of 2016, item 108) identification measurements were conducted of flue gases temperature distribution in the WR-25 boiler combustion chamber. Measurement points were located in the representative zones of the combustion chamber on the left and right wall, with consideration to technical capabilities of making measurement nozzles. Layout of measurement points in the boiler is schematically presented in figure 1.

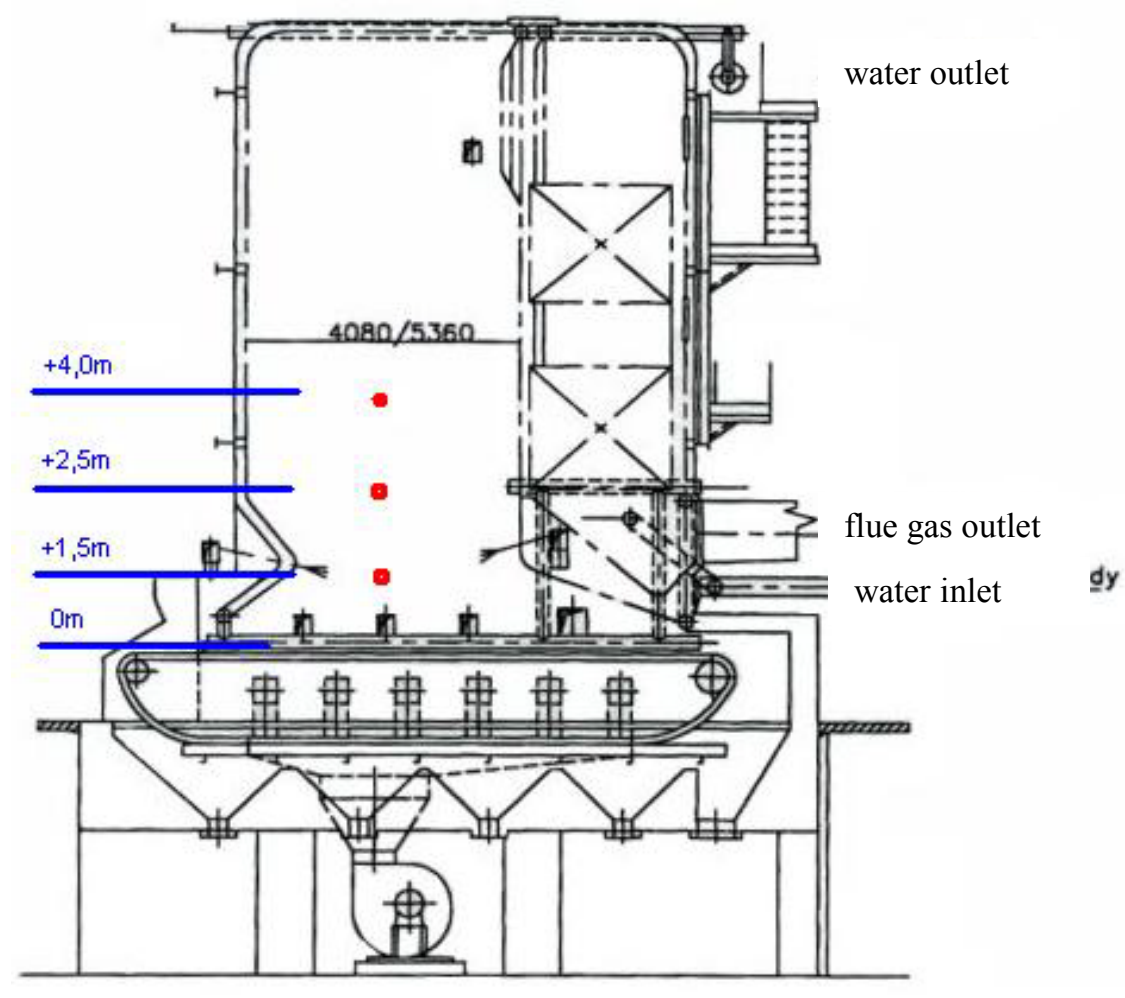

Fig. 1. Diagram of temperature measurement points layout in the WR-25 boiler combustion chamber.

Measurements were conducted by means of temperature sensors - NiCr-NiAl thermocouples of $\mathrm{K}$ type and Agillent recorder. Temperatures were recorded at the same depth in the combustion chamber to which the temperature sensor was inserted. Quantity of flue gas flowing through the combustion chamber was determined by recalculating the flux of gases determined during the measurement of flue gas dusting into conditions in the chamber. 


\section{Results and discussion}

\subsection{Properties of combusted materials}

SRF was a loose material, shredded to aggregate of granulation below $40 \mathrm{~mm}$. It was a mix of fractions of plastics, rubber, fabric, paper, cardboard and wood coming from automotive waste processing, and coal slurry with a small quantity of halloysite.

Results of physico-chemical properties determination of all combusted materials are presented in tables 1-2.

Table 1. Physico-chemical properties of combusted materials.

\begin{tabular}{|c|c|c|c|c|c|}
\hline Parameter & Symbol & Unit & Hard coal & SRF & $\begin{array}{c}\text { Blend of coal } \\
\text { and 10\% } \\
\text { SRF }\end{array}$ \\
\hline Moisture content & $\mathrm{W}_{\mathrm{t}}{ }^{\mathrm{r}}$ & {$[\%]$} & 8.0 & 3.1 & 13.6 \\
\hline Ash content & $\mathrm{A}^{\mathrm{d}}$ & {$[\%]$} & 21.5 & 24.4 & 22.0 \\
\hline Volatile matter & $\mathrm{V}^{\text {daf }}$ & {$[\%]$} & 36.45 & 89.40 & 40.90 \\
\hline Coal content & $\mathrm{C}^{\mathrm{d}}$ & {$[\%]$} & 67.50 & 56.50 & 68.80 \\
\hline Hydrogen content & $\mathrm{H}^{\mathrm{d}}$ & {$[\%]$} & 4.10 & 7.15 & 4.31 \\
\hline Sulphur content & $\mathrm{S}^{\mathrm{d}}{ }_{\mathrm{t}}$ & {$[\%]$} & 0.50 & 0.25 & 0.45 \\
\hline Nitrogen content & $\mathrm{N}^{\mathrm{d}}$ & {$[\%]$} & 1.20 & 0.78 & 1.28 \\
\hline Chlorine content & $\mathrm{Cl}^{\mathrm{d}}$ & {$[\%]$} & 0.20 & 0.86 & 0.39 \\
\hline Fluorine content & $\mathrm{F}^{\mathrm{d}}$ & {$[\%]$} & 0.02 & 0.08 & 0.01 \\
\hline Caloryfic value & $\mathrm{Q}^{\mathrm{a}}{ }_{\mathrm{s}}$ & {$[\mathrm{kJ} / \mathrm{kg}]$} & 26754 & 29216 & 28406 \\
\hline Gross caloryfic value & $\mathrm{Q}^{\mathrm{r}}{ }_{\mathrm{i}}$ & {$[\mathrm{kJ} / \mathrm{kg}]$} & 23861 & 27357 & 23797 \\
\hline Bulk density & $(\mathrm{BD})^{\mathrm{r}}$ & {$\left[\mathrm{kg} / \mathrm{m}^{3}\right]$} & 877 & 186 & 812 \\
\hline Bulk density & $(\mathrm{BD})^{\mathrm{d}}$ & {$\left[\mathrm{kg} / \mathrm{m}^{3}\right]$} & 807 & 180 & 702 \\
\hline
\end{tabular}

Where, indices $d$, daf, $r, a$ from tab. 1 mean: dry, dry ash free, as received, analytical, respectively.

SRF was characteristic of good energy parameters, similar to the base hard coal. However, SFR contained double the quantity of volatile particles. Despite low density, after SRF (with $10 \%$ weight share) was mixed with hard coal - density of the blend was close to the one of coal. It shall be noted that SRF contained 4 times more chlorine than the examined hard coal.

Table 2. Metals content in combusted materials.

\begin{tabular}{|c|c|c|c|c|}
\hline Symbol & Unit & Hard coal & SRF & Blend of coal and 10\% SRF \\
\hline $\mathrm{Pb}^{\mathrm{d}}$ & {$\left[\mathrm{mg} / \mathrm{kg}_{\text {d.m. }}\right]$} & 15.30 & 102.00 & 27.70 \\
\hline $\mathrm{Cd}^{\mathrm{d}}$ & {$\left[\mathrm{mg} / \mathrm{kg}_{\text {d.m. }}\right]$} & 0.166 & 2.180 & $<0.204$ \\
\hline $\mathrm{Cu}^{\mathrm{d}}$ & {$\left[\mathrm{mg} / \mathrm{kg}_{\text {d.m. }}\right]$} & 29.4 & 2207.0 & 39.8 \\
\hline $\mathrm{Cr}^{\mathrm{d}}$ & {$\left[\mathrm{mg} / \mathrm{kg}_{\text {d.m. }}\right]$} & 22.1 & 345.0 & 24.2 \\
\hline $\mathrm{Ni}^{\mathrm{d}}$ & {$\left[\mathrm{mg} / \mathrm{kg}_{\text {d.m. }}\right]$} & 14.4 & 160.0 & 19.6 \\
\hline $\mathrm{Hg}^{\mathrm{d}}$ & {$\left[\mathrm{mg} / \mathrm{kg}_{\text {d.m. }}\right]$} & 0.039 & 0.245 & 0.069 \\
\hline $\mathrm{V}^{\mathrm{d}}$ & {$\left[\mathrm{mg} / \mathrm{kg}_{\text {d.m. }}\right]$} & 47.4 & 23.0 & 37.1 \\
\hline $\mathrm{Sb}^{\mathrm{d}}$ & {$\left[\mathrm{mg} / \mathrm{kg}_{\text {d.m. }}\right]$} & 1.44 & 245.00 & 26.50 \\
\hline $\mathrm{Co}^{\mathrm{d}}$ & {$\left[\mathrm{mg} / \mathrm{kg}_{\text {d.m. }}\right]$} & 7.5 & 95.3 & 15.3 \\
\hline $\mathrm{As}^{\mathrm{d}}$ & {$\left[\mathrm{mg} / \mathrm{kg}_{\text {d.m. }}\right]$} & 1.800 & 1.860 & $<0.714$ \\
\hline $\mathrm{Mn}^{\mathrm{d}}$ & {$\left[\mathrm{mg} / \mathrm{kg}_{\text {d.m. }}\right]$} & 188.0 & 443.0 & 195.0 \\
\hline $\mathrm{Sum}$ & {$\left[\mathrm{mg} / \mathrm{kg}_{\text {d.m. }}\right]$} & 327.54 & 3624.59 & 386.19 \\
\hline
\end{tabular}

Where, superscripts $d$ mean dry state and subscripts $d m$, dry matter state, respectively. 
SRF contained a lot more heavy metals in comparison to hard coal, in particular: copper, chromium, nickel and cobalt, which is related to the origin of waste materials it was made of. A small share of alternative fuel in the blend (approx. 10\%) results in the fact that the content of heavy metals in the blend and their content in coal are on comparable level.

\subsection{Establishing duration of the flue gases residence in the temperature exceeding $850^{\circ} \mathrm{C}$}

Measurement results of the flue gases temperature distribution in combustion chamber of the WR-25 boiler are presented in figure 2 .

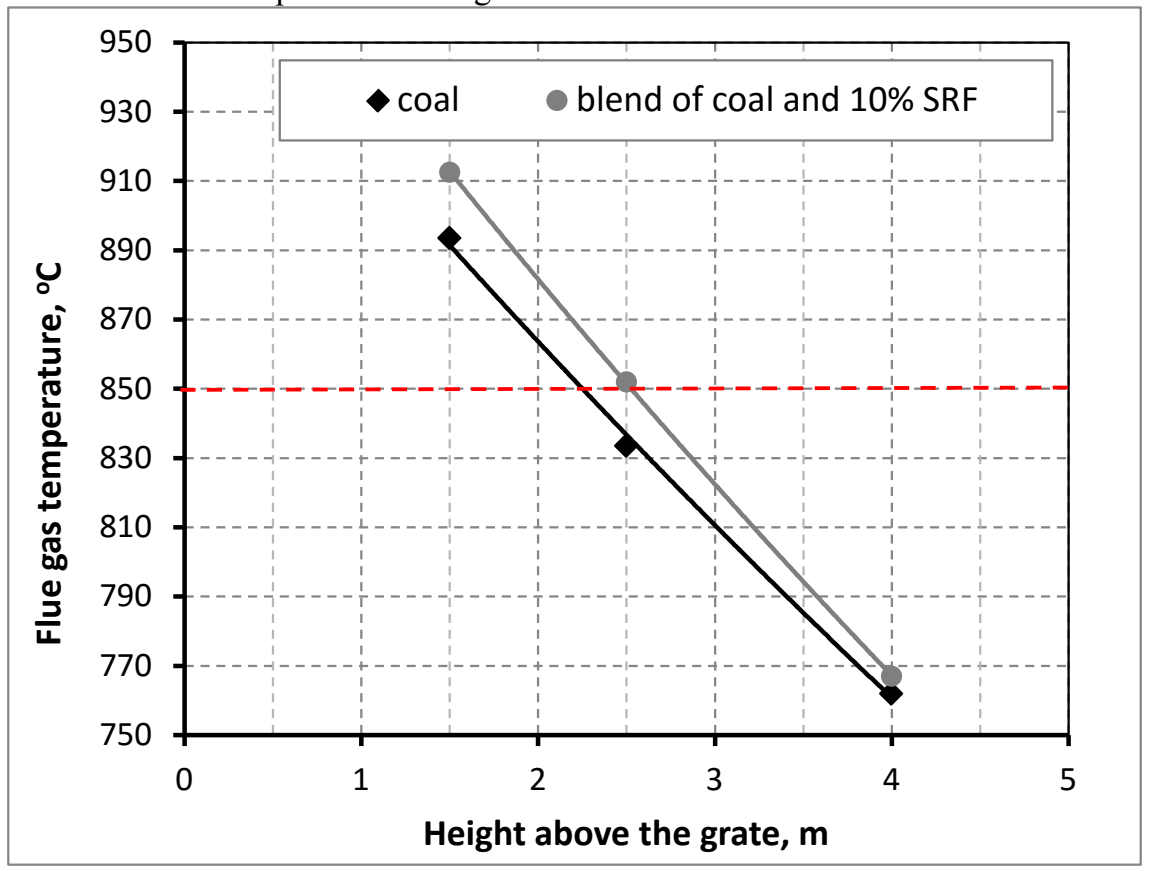

Fig.2. Distribution of average flue gases temperature during combustion of hard coal and blend of coal and $10 \% \mathrm{SRF}$.

During co-combustion of fuel mix containing $10 \% \mathrm{SRF}$, the average temperature of flue gases was raised in all measurement points of the combustion chamber. Both SRF and blend of coal and $10 \%$ SRF contained more volatile particles in comparison to coal which resulted in the fact that substances released in the degassing process were combusted in higher zones of the combustion chamber.

To determine the mean duration of the flue gases residence in the combustion chamber, the following assumptions were made:

- piston flow model of the flue gas flux flow in combustion chamber,

- temperature of flue gas was taken as a positive value recorded in points between the grate and $4.0 \mathrm{~m}$ level,

- $\quad$ as the average flow distance of $2.35 \mathrm{~m}$ was taken for combustion of coal and $2.5 \mathrm{~m}$ for combustion of the coal and waste mix,

- the actual flux of flue gas volume in the conditions of the determined average flue gas temperature in the combustion chamber was calculated on the basis of the flue gas volume flux behind the boiler determined during tests.

Calculation results are presented in table 3. 
Table 3. Statement of measurement results of flue gas flow in the WR- 25 boiler during tests.

\begin{tabular}{|c|c|c|c|}
\hline Parameter & Unit & Hard coal & Blend of coal and 10\% SRF \\
\hline $\begin{array}{c}\text { Velocity of flue gas in the } \\
\text { combustion chamber }\end{array}$ & {$[\mathrm{m} / \mathrm{s}]$} & 2.08 & 1.92 \\
\hline Flue gas flux (real conditions) & {$\left[\mathrm{m}^{3} / \mathrm{h}\right]$} & 154904 & 142953 \\
\hline Flue gas density & {$\left[\mathrm{kg} / \mathrm{m}^{3}\right]$} & 0.29 & 0.30 \\
\hline Height of the zone above $850^{\circ} \mathrm{C}$ & {$[\mathrm{m}]$} & 2.35 & 2.50 \\
\hline $\begin{array}{c}\text { Residence time of flue gas in zone } \\
\text { above } 850^{\circ} \mathrm{C}\end{array}$ & {$[\mathrm{s}]$} & 1.1 & 1.3 \\
\hline
\end{tabular}

Calculation results show that the tested WR-25 boiler failed to maintain the legislative requirements for thermal conversion of waste during tests. The WR-25 boiler structure is adapted for a specific type of fuel (hard coal) and it does not allow for environmentally safe co-combustion of waste.

\subsection{By-products of combustion/co-combustion}

Tables 4 and 5 present test results of by-products of hard coal and SRF combustion/co-combustion.

Table 4. Combustible particles content in slag and fly ash obtained during the tests.

\begin{tabular}{|c|c|c|c|c|c|}
\hline \multirow{2}{*}{ Parameter } & \multirow{2}{*}{ Unit } & \multicolumn{2}{|c|}{ Hard coal } & \multicolumn{2}{c|}{ Blend of coal and 10\% SRF } \\
\cline { 3 - 6 } & & ash & fly ash & ash & fly ash \\
\hline Flammable parts & {$[\%]$} & 5.78 & 29.73 & 15.63 & 33.38 \\
\hline
\end{tabular}

Both the slag and fly ash from co-combustion of SRF have higher content of combustible particles in comparison to by-products of hard coal combustion. This contributes to the increase of losses in the boiler energy balance. It shall be noted, however, that no legislative obligation to maintain a adequate level of process by-products aftercombustion has been specified.

Table 5. Metals content in ash and fly ash.

\begin{tabular}{|c|c|c|c|c|c|}
\hline \multirow{2}{*}{ Symbol } & \multirow{2}{*}{ Unit } & \multicolumn{2}{|c|}{ Hard coal } & \multicolumn{2}{c|}{$\begin{array}{c}\text { Blend of coal and 10\% } \\
\text { SRF }\end{array}$} \\
\cline { 3 - 6 } & & ash & fly ash & fly ash & ash \\
\hline $\mathrm{Pb}^{\mathrm{d}}$ & {$\left[\mathrm{mg} / \mathrm{kg}_{\text {d.m. }}\right]$} & 68.0 & 154.0 & 32.9 & 128.0 \\
\hline $\mathrm{Cd}^{\mathrm{d}}$ & {$\left[\mathrm{mg} / \mathrm{kg}_{\text {d.m. }}\right]$} & 0.41 & 3.48 & $<0.27$ & 5.04 \\
\hline $\mathrm{Cu}^{\mathrm{d}}$ & {$\left[\mathrm{mg} / \mathrm{kg}_{\text {d.m. }}\right]$} & 56.5 & 321.0 & 730.0 & 356.0 \\
\hline $\mathrm{Cr}^{\mathrm{d}}$ & {$\left[\mathrm{mg} / \mathrm{kg}_{\text {d.m. }}\right]$} & 87.9 & 148.0 & 224.0 & 143.0 \\
\hline $\mathrm{Ni}^{\mathrm{d}}$ & {$\left[\mathrm{mg} / \mathrm{kg}_{\text {d.m. }}\right]$} & 656 & 205 & 90 & 215 \\
\hline $\mathrm{Hg}^{\mathrm{d}}$ & {$\left[\mathrm{mg} / \mathrm{kg}_{\text {d.m. }}\right]$} & 0.006 & 1.000 & 0.009 & 3.346 \\
\hline $\mathrm{V}^{\mathrm{d}}$ & {$\left[\mathrm{mg} / \mathrm{kg}_{\text {d.m. }}\right]$} & 162.00 & 3.71 & 144.00 & 353.00 \\
\hline $\mathrm{Sb}^{\mathrm{d}}$ & {$\left[\mathrm{mg} / \mathrm{kg}_{\text {d.m. }}\right]$} & 3.79 & 36.5 & 10.1 & 169.0 \\
\hline $\mathrm{Co}^{\mathrm{d}}$ & {$\left[\mathrm{mg} / \mathrm{kg}_{\text {d.m. }}\right]$} & 22.6 & 65.7 & 56.2 & 118.0 \\
\hline $\mathrm{As}^{\mathrm{d}}$ & {$\left[\mathrm{mg} / \mathrm{kg}_{\text {d.m. }}\right]$} & $<1.7$ & 41.5 & 1.7 & 25.3 \\
\hline $\mathrm{Mn}^{\mathrm{d}}$ & {$\left[\mathrm{mg} / \mathrm{kg}_{\text {d.m. }}\right]$} & 757 & 697 & 866 & 560 \\
\hline $\mathrm{Sum}$ & {$\left[\mathrm{mg} / \mathrm{kg}_{\text {d.m. }}\right]$} & 1815.904 & 1676.89 & 2155.179 & 2075.686 \\
\hline
\end{tabular}

Where, superscripts $d$ mean dry state and subscripts $d m$, dry matter state, respectively. 
Both slag and fly ash from combustion of coal blend with $10 \%$ SRF contain in total higher quantities of heavy metals than products of coal combustion which results directly from their higher content in the combusted material.

\subsection{Statement of energy research results} table 6.

Specific parameters used for establishing the boiler energy balance is presented in

Table 6. The WR-25 boiler energy balance.

\begin{tabular}{|c|c|c|c|c|}
\hline \multicolumn{2}{|c|}{ Parameter } & Unit & $\begin{array}{l}\text { Hard } \\
\text { coal }\end{array}$ & $\begin{array}{c}\text { Blend of coal and } \\
10 \% \text { SRF }\end{array}$ \\
\hline \multicolumn{2}{|r|}{ Water flow through the boiler } & {$[\mathrm{Mg} / \mathrm{h}]$} & 318.98 & 324.35 \\
\hline \multicolumn{2}{|r|}{ Thermal input of the boiler } & {$\left[\mathrm{MW}_{\mathrm{t}}\right]$} & 17.352 & 18.835 \\
\hline \multirow{2}{*}{\multicolumn{2}{|c|}{$\frac{\text { Mean fuel flux }}{\text { Flux of chemical energy of fuel }}$}} & {$[\mathrm{Mg} / \mathrm{h}]$} & 2.90 & 3.08 \\
\hline & & {$[\mathrm{MW}]$} & 19.221 & 20.388 \\
\hline \multirow{4}{*}{ Losses } & physical outlet of flue gas & $\begin{array}{c}{[\mathrm{MW}]} \\
{[\%]}\end{array}$ & $\begin{array}{l}1.47 \\
7.63\end{array}$ & $\begin{array}{l}1.43 \\
7.02\end{array}$ \\
\hline & of not combusted $\mathrm{CO}$ in flue gas & $\begin{array}{c}{[\mathrm{MW}]} \\
{[\%]}\end{array}$ & $\begin{array}{l}0.01 \\
0.04\end{array}$ & $\begin{array}{l}0.01 \\
0.03\end{array}$ \\
\hline & $\begin{array}{c}\text { enthalpy and content of } \\
\text { combustible particles in fly ashes } \\
\text { and slag }\end{array}$ & $\begin{array}{c}{[\mathrm{MW}]} \\
{[\%]}\end{array}$ & $\begin{array}{l}0.62 \\
3.24\end{array}$ & $\begin{array}{l}1.06 \\
5.20\end{array}$ \\
\hline & $\begin{array}{l}\text { to the environment } \\
\text { (radiation and convection) }\end{array}$ & $\begin{array}{c}{[\mathrm{MW}]} \\
{[\%]}\end{array}$ & $\begin{array}{l}0.23 \\
1.19\end{array}$ & $\begin{array}{l}0.24 \\
1.17\end{array}$ \\
\hline \multicolumn{2}{|c|}{$\begin{array}{l}\text { Boiler energy efficiency (gross) } \\
\text { Uncertainty }\end{array}$} & {$[\%]$} & $\begin{array}{l}87.26 \\
\pm 1.22 \\
\end{array}$ & $\begin{array}{l}86.63 \\
\pm 1.51 \\
\end{array}$ \\
\hline
\end{tabular}

No process difficulties were noted in the operation of WR-25 boiler installation during any of the two tests. The WR-25 boiler worked with similar efficiency, and with minimally lower (by $0.6 \%$ ) performance arising mainly from unburned slag and fly ash.

\subsection{Emission of pollution to the air}

Table 7 presents emissions from combustion of coal and co-combustion of coal with $10 \%$ SRF in relation to emission standards which shall be maintained during combustion of hard coal in WR-25 boiler and during co-combustion of waste.

Table 7. Comparison of pollution emissions* during combustion of hard coal and a blend of coal with $10 \%$ SRF with the emission standards valid for the WR-25 boiler installation during combustion of hard coal and co-combustion of waste.

\begin{tabular}{|c|c|c|c|c|c|}
\hline \multirow{2}{*}{$\begin{array}{c}\text { Emitted } \\
\text { substance }\end{array}$} & Unit & \multicolumn{2}{|c|}{ Measured emission } & \multicolumn{2}{c|}{ Permitted emission } \\
\cline { 3 - 6 } & combustion & $\begin{array}{c}\text { combustion } \\
\text { of hard coal } \\
\text { coal and of } \\
\text { 10\% SRF }\end{array}$ & $\begin{array}{c}\text { co- } \\
\text { combustio } \\
\text { n of hard } \\
\text { coal }\end{array}$ & $\begin{array}{c}\text { co- } \\
\text { combustion } \\
\text { of waste and } \\
\text { coal }\end{array}$ \\
\hline $\mathrm{SO}_{2}$ & {$\left[\mathrm{mg} / \mathrm{m}^{3} \mathrm{u}\right]$} & 953.4 & 921.4 & 1500 & 1386.5 \\
\hline $\mathrm{NO}_{\mathrm{x}}$ & {$\left[\mathrm{mg} / \mathrm{m}_{\mathrm{u}}^{3}\right]$} & 407.4 & 356.0 & 400 & 391.1 \\
\hline $\mathrm{Dust}$ & {$\left[\mathrm{mg} / \mathrm{m}_{\mathrm{u}}^{3}\right]$} & 141.6 & 243.7 & 400 & 47.2 \\
\hline $\mathrm{CO}$ & {$\left[\mathrm{mg} / \mathrm{m}_{\mathrm{u}}^{3}\right]$} & 39.0 & 39.0 & - & 41.6 \\
\hline
\end{tabular}




\begin{tabular}{|c|c|c|c|c|c|}
\hline $\mathrm{HCl}$ & {$\left[\mathrm{mg} / \mathrm{m}^{3}{ }_{\mathrm{u}}\right]$} & 82.5 & 208.6 & - & 77.1 \\
\hline $\mathrm{HF}$ & {$\left[\mathrm{mg} / \mathrm{m}_{\mathrm{u}}^{3}\right]$} & 1.40 & 1.00 & - & 1.45 \\
\hline $\mathrm{TOC}$ & {$\left[\mathrm{mg} / \mathrm{m}^{3}{ }_{\mathrm{u}}\right]$} & 9.3 & 1.9 & - & 9.7 \\
\hline $\mathrm{Cd}+\mathrm{Tl}$ & {$\left[\mathrm{mg} / \mathrm{m}^{3}{ }_{\mathrm{u}}\right]$} & 0.0005 & 0.0012 & - & 0.05 \\
\hline $\mathrm{Hg}$ & {$\left[\mathrm{mg} / \mathrm{m}^{3}{ }_{\mathrm{u}}\right]$} & 0.00014 & 0.00080 & - & 0.05 \\
\hline $\begin{array}{c}\mathrm{Sb}+\mathrm{As}+\mathrm{Pb}+\mathrm{Cr}+ \\
\mathrm{Co}+\mathrm{Cu}+\mathrm{Mn}+\mathrm{Ni}+\mathrm{V}\end{array}$ & {$\left[\mathrm{mg} / \mathrm{m}^{3}{ }_{\mathrm{u}}\right]$} & 0.236 & 0.507 & - & 0.5 \\
\hline $\mathrm{PCDD} / \mathrm{DF}$ & {$\left[\mathrm{ng} / \mathrm{m}_{\mathrm{u}}^{3}\right]$} & 0.017 & 0.232 & - & 0.1 \\
\hline
\end{tabular}

* Substance concentration in flue gas in stipulated conditions recalculated into $6 \%$ oxygen content in flue gas.

During combustion of hard coal, the $\mathrm{NO}_{\mathrm{x}}$ emission exceeded minimum permitted levels however, in the longer-term measurement period, with little adjustment of the boiler process parameters setup (supply of fuel and air for combustion) - this value may be maintained on the required level.

During combustion of hard coal blend with 10\% SFR in the WR-25 boiler, the emission standards valid for this installation were complied with in relation to combustion of fuel used so far. Emissions of $\mathrm{SO}_{2}$ and $\mathrm{NO}_{\mathrm{x}}$ were on the same level, and even slightly lower, compared to hard coal combustion. In case of SRF co-combustion, emission of dust was considerably increased in comparison to hard coal combustion. It shall be stressed however, that results of these measurements are within the range of permitted emission standards for the tested installation.

No considerable changes in emission volume of the monitored pollutions were observed during any of the two measurement tests, which proves stability of the combustion process.

It shall be noted that comparing the emission test results to combustion of solid fuels is solely of theoretical nature, because in the current legal situation SRF is treated as waste other than hazardous and it is identified by 191210 code and its use for power engineering depends on meeting the requirements for thermal conversion of waste. It is connected with much broader scope of emission monitoring and much stricter level of the required emission standards.

Comparing the obtained emission levels to the values permitted for co-combustion of waste, it shall be stated that during co-combustion of SRF with coal, the following concentrations were exceeded:

- hydrogen chloride - almost three-fold,

- dust whose level emission level significantly deviates from the permitted value,

- heavy metals: $\mathrm{Sb}+\mathrm{As}+\mathrm{Pb}+\mathrm{Cr}+\mathrm{Co}+\mathrm{Cu}+\mathrm{Mn}+\mathrm{Ni}+\mathrm{V}$, very little,

- polychlorinated dioxins and furans (more than two-fold), which arises from relatively high chlorine content in SRF in comparison to coal.

The presented data arise from the fact that the WR-25 boiler installation in which the tests were made is not equipped with the flue gas purification system adapted to the emission requirements for combustion/co-combustion of waste.

\section{Conclusion}

The industrial research showed that it is possible to meet the emission requirements for WR-25 boiler in relation to the base fuel (hard coal) in spite of its partial replacement with SRF.

However, undertaking combustion/ co-combustion of SRF it shall be kept in mind that it is a waste material and such activity is subject to legislative requirements applicable for thermal processing of waste. 
Considering the aforementioned circumstances it was stated that combustion of a mix of hard coal with $10 \%$ SFR share in the WR-25 boiler causes that emission standards are exceed in relation to: $\mathrm{HCl}$, dust, heavy metals, and dioxins and furans.

Also the time of the flue gases residence in the area where the temperature exceeds $850^{\circ} \mathrm{C}$ is too short $(1.3 \mathrm{sec}$.) to satisfy the legislative requirements specified for thermal processing of waste $(2 \mathrm{sec}$.)

SRF co-combustion with hard coal in the WR-25 boiler requires modernisation of the combustion chamber design (e.g. change in heat exchangers location) and in the flue gas purification system (e.g. adding a more effective dust removal system, and system of heavy metals and dioxins removal).

\section{References}

1. A. Sobolewski, R. Wasielewski, K. Dreszer, S. Stelmach, Przem Chem, 85, 1080-1084 (2006)

2. R. Wasielewski, A. Sobolewski, Przem Chem, 90, 1000-1005 (2015)

3. Refuse derived fuel, current practice and perspectives. Final Report (European Commision - Directoriate General Environment, 2003)

4. S. Thiel, K. J. Kozmensky, Waste Manage Res., 4, 392-403 (2012)

5. L. Lombardi, E. Carnevale, A. Corti, Waste Manage, 37, 26-44 (2015)

6. T. Hilber, J. Maier, G. Scheffknecht, M. Agraniotis, P. Grammelis, E. Kakaras, T. Glorius, U. Becker, W. Derichs, H.P. De Jong, L. Torri, J. Air Waste Manag Assoc, 57, 1178-1189 (2007)

7. L. Del Zotto, A. Tallini, G. Di Simone, G. Molinari, L. Cedola, Energy Procedia, 81, 319-338 (2015)

8. P. Krawczyk, J. Szczygieł, Rynek Energii, 109, 91-96 (2013)

9. G. Wielgosiński, O. Namiecińska, Nowa Energia, 2-3, 33-40 (2015)

10. R. Wasielewski, B. Tora, Polit Energ, 11, 129-138 (2008) 